\title{
MODELING THE BEHAVIOR OF RAIN GARDENS
}

\author{
HARSHO SANYAL ${ }^{1}$, YARA YASSER ELBOROLOSY ${ }^{2} \&$ JOSEPH CATALDO $^{1}$ \\ ${ }^{1}$ The Cooper Union for the Advancement of Science and Art, USA \\ ${ }^{2}$ United States Army Corps of Engineers, USA
}

\begin{abstract}
Globally, many cities have an overreliance on gray infrastructure, which does little to prevent flooding, and further contaminates the runoff, exacerbating its environmental effects. Green infrastructure (GI) has emerged as an alternative, which works by utilizing natural hydrology through the incorporation of permeable surfaces, retention, and water filtration. GI practices can include structures such as green roofs, permeable pavements, and rain gardens. Rain gardens are among the highest-priority GI practices in urban areas, due to their soil suitability, space requirements, and high nitrogen removal from stormwater. They are built with layers of gravel, geotextile fabric, engineered soil, and a hardy plant species. Stormwater is captured and retained, before eventually exiting via outlets, sewer piping, or evapotranspiration. This analysis of rain gardens includes an examination of stormwater infiltration and storage of a hypothetical design at a NYC location. Furthermore, "greened acres" (equivalent impervious area for stormwater) are presented for the project, to highlight the effectiveness of stormwater quantity management. Additionally, runoff quality was experimentally measured using a physical model of a rain garden, where nitrogen concentration is measured before and after to determine change in runoff quality. This concept is based on a previous green roof study, where nitrogen removal in soil was determined after wood mulch (which is known to use up excess nitrogen) was added. This previous experiment showed a $22 \%$ reduction in nitrates after a week of soil mixed with wood mulch. The modelled rain garden was able to capture $80 \%$ of the nitrogen in the inflow for a single storm event, but only $60 \%$ for a second storm event. Additionally, previously present nitrogen leached from the soil into the runoff, significantly reducing its effectiveness. Further research of the nitrogen removal by rain gardens is recommended.
\end{abstract}

Keywords: rain garden, green infrastructure, nitrogen capture, runoff, stormwater, green roof, stormwater management.

\section{INTRODUCTION}

Beginning at the turn of the century, the New York government began to prioritize improved water and air quality. From 2002 to 2010 , $\$ 6$ billion was invested in water quality alone. In 2010, the New York City Department of Environmental Protection (NYCDEP) released its first Annual Green Infrastructure report, initiating the focused development of green infrastructure in New York City. This would include porous pavements, green and blue roofs, bioswales, and many more [1].

The purpose of this report is to study and develop a green infrastructure project in New York City. This GI practice is a rain garden. Rain gardens can either be connected to sewer systems, or separate, and serve the primary purpose of reducing sewage overflows, and filtering the water which flows into the sewers. The rain garden is analyzed to determine its effectiveness of water retention and filtration, using resources provided by the NYCDEP.

To further study a rain garden's effect on soil retention and filtration, a model rain garden was designed and constructed. Various parameters were recorded and analyzed to experimentally determine its effectiveness at nitrogen removal. This study was carried out in the Fluids Laboratory at The Cooper Union for the Advancement of Science and Art. 


\section{BACKGROUND}

\subsection{Emergence of green infrastructure}

The environmental health of the globe faces many struggles, whether it be with water quality, ecosystem health, or rising temperatures from climate change. Many of these can be attributed to a heavy overreliance by societies on grey infrastructure, the conventional stormwater management system. Gray infrastructure, which uses impervious structures such as concrete, storm drains, and pipes, transfers (often untreated) stormwater from the streets into natural waterways via the sewer system. Such designs do little to ease flood management, and actually reduce runoff water quality as contaminants such as pathogens, heavy metals, and sediment are picked up from impervious surfaces [2]. The Natural Resources Defense Council reports that 10 trillion gallons of this polluted runoff eventually enters natural bodies of water, harming the ecosystem and water source for human consumption.

Green infrastructure (GI) has emerged as a viable alternative. It is designed to imitate natural hydrology, incorporating porous surfaces which can absorb up to $90 \%$ of the stormwater runoff that reaches them. In absorbing this runoff, GI reduces the stress on sewer systems and mitigates risk of flooding [2]. Furthermore, the quality of the runoff is filtered through processes such as adsorption, filtration, and plant uptake. GI can also generate positive effects such as air quality improvement (by absorbing pollutants from the air), preservation of ecological habitats (by reducing erosion-causing runoff], and increased resilience against climate change (by combating urban heat island effect and reducing temperatures, while absorbing potential floodwater) [3].

\subsection{Criteria for green infrastructure}

There are numerous forms of GI which can be incorporated in an urban setting, which are useful for stormwater management. Criteria for these can include space availability and soil suitability. Fig. 1 from NYCDEP's Stormwater Management Program shows numerous green infrastructure practices such as green roofs, sand roofs, and rain gardens prioritized by these parameters.

Furthermore, total nitrogen (TN) removal can be used as a measurement of a GI type's effectiveness. Nitrogen occurs naturally in aquatic ecosystems, but in excess it can be harmful. While green roofs have a TN removal rate of 35\%, sand filters are more effective at $40 \%$, and rain gardens are expected to remove $100 \%$ of total nitrogen [5].

\begin{tabular}{|c|c|c|c|}
\hline $\begin{array}{l}\text { On-Site Vegetated } \\
\text { Infiltration }\end{array}$ & $\begin{array}{l}\text { Sub-Surface Infiltration } \\
\text { and Green Roof }\end{array}$ & $\begin{array}{l}\text { Vegetated Detention } \\
\text { with Treatment }\end{array}$ & $\begin{array}{l}\text { Physical Treatment and } \\
\text { Green Roof }\end{array}$ \\
\hline $\begin{array}{l}\text { Rain Gardens and } \\
\text { Bioretention } \\
\text { Soil Suitability }\end{array}$ & $\begin{array}{l}\text { Permeable Pavement, } \\
\text { Infiltration Trenches, Turf } \\
\text { Fields, Green Roof }\end{array}$ & $\begin{array}{l}\text { Vegetated Open Swales, } \\
\text { Constructed Wetlands, } \\
\text { Bioretention with } \\
\text { Underdrains, Ponds, Sheet } \\
\text { Flow to Riparian Area }\end{array}$ & $\begin{array}{l}\text { Sand Filters, Green Roof, } \\
\text { Other Approved Filtration } \\
\text { Technologies }\end{array}$ \\
\hline $\begin{array}{l}\text { High } \\
\text { Space Availability }\end{array}$ & High & Low & Low \\
\hline High & Low & High & Low \\
\hline
\end{tabular}

Figure 1: Hierarchy of stormwater practices by preference [4]. 
Due to their high efficiency and suitability, rain gardens were chosen for the purpose of this project. Bioswales and rain gardens are lengths of vegetation usually found on sidewalks. Functionality-wise, they are nearly identical, with the key difference being that bioswales have 4 feet of equally divided engineered soil and stone subbase underneath (with 9 feet separating the surface from the bedrock), whereas rain gardens have only 3 feet of engineered soil and stone subbase (with 7 feet between the soil surface and bedrock) [6]. The primary purpose of rain gardens and bioswales is to collect rainwater from impervious surface runoff, preventing it from putting excessive stress on sewer systems. Only when a rain garden/bioswale has reached full capacity, will stormwater begin overflowing from the outlet, and enter the sewers via the catch basin [3].

\section{PREVIOUS MODELLED GREEN ROOF STUDY}

The model rain garden study was preceded by another study at the Cooper Union, which examined a model green roof based on the green roof at New York City's Javits Center. The purpose of that study was to investigate the effects on soil of excess nitrogen or trace heavy metals, the latter of which can be linked to Javits' proximity with smoke from the Lincoln Tunnel. Strategies were then designed for remediation of both contaminants, but due to time and resource constraints, only the nitrate studies were carried out in the laboratory.

\subsection{Research findings}

The effects of nitrates and trace heavy metals were studied from a variety of sources, and compiled in an unpublished report. As with other salts, nitrates in soil increase osmotic pressure outside of the plant roots, reducing the amount of water they can take in against the concentration gradient. Furthermore, excess nitrogen can be leached out of the soil by runoff water, which can enter aquatic systems and cause rapid algal growth. This process, known as eutrophication, can lead to reduced dissolved oxygen levels and limited penetration of sunlight into the water. Regarding heavy metals, harmful effects include a change in enzyme production, reducing plant biodiversity and richness. Additionally, heavy metals can accumulate in the food chain, affecting animals and humans.

Processes for soil remediation vary. For nitrate remediation, usage of wood mulch to tie up excess nitrogen was seen to be an effective strategy. Heavy metals were primarily managed by bioremediation, planting crops which have rapid growth, far reaching roots, high biomass, and can handle high levels of trace metals. These plants soak metals out of the soil, before being extracted and incinerated in a closed furnace [7].

\subsection{Setup}

The study was designed to examine the effect of wood mulch on nitrate concentration in soil. It was carried out over the month of December 2020 in the Fluids Laboratory at 41 Cooper Square, New York, NY. The project setup is shown in Fig. 2.

Initially, two 2 feet $\times 4$ feet boxes had holes drilled along one of the shorter ends. This end would be covered by a PVC pipe, to allow a path for runoff. These boxes were coated with felt to cover any cracks, after which they were both filled up to a height of 1 foot with soil. The upper layer of soil for Box A (the experimental box) was mixed with four quarts of wood mulch. Each box then had two moisture probes placed at the points shown in Fig. 2. The first trial date established nitrogen levels in runoff for both boxes, and the second trial date determined the effect of wood mulch on nitrogen capture [7]. 

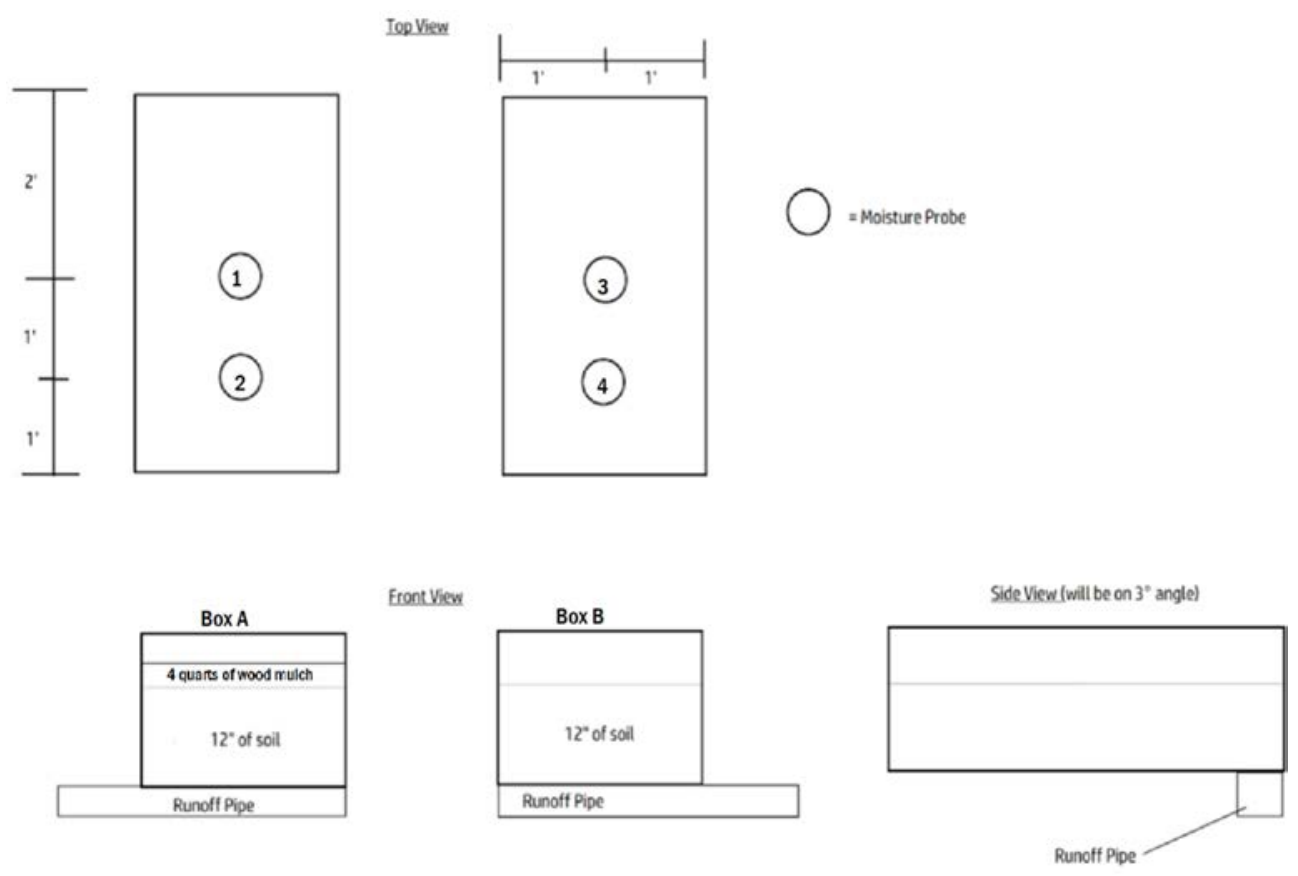

Figure 2: Diagram of experimental setup for model green roof base.

\subsection{Analysis}

The parameters measured included soil moisture, soil temperature, and nitrate concentration of runoff. The experimental trials were carried out on 1 December 2020 and 11 December 2020. As seen in Table 1, soil moisture increased after running water through the system, while soil temperature remained consistent on the first date and increased slightly on the second date. Table 2 shows how runoff tended in larger quantities from the box with wood

Table 1: TEROS soil probe data for tap water inflow into green roof.

\begin{tabular}{|c|c|c|c|c|c|}
\hline \multicolumn{2}{|c|}{} & \multicolumn{2}{|c|}{ Trial 1 (1 December 2020) } & \multicolumn{2}{c|}{ Trial 1 (11 December 2020) } \\
\hline \multirow{3}{*}{$\begin{array}{c}\text { Before } \\
\text { inflow }\end{array}$} & $\begin{array}{c}\text { Probe } \\
\text { number }\end{array}$ & $\begin{array}{c}\text { Water } \\
\text { content } \\
\left(\mathrm{m}^{3} / \mathrm{m}^{3}\right)\end{array}$ & $\begin{array}{c}\text { Soil temperature } \\
\left({ }^{\circ} \mathrm{C}\right)\end{array}$ & $\begin{array}{c}\text { Water } \\
\text { content } \\
\left(\mathrm{m}^{3} / \mathrm{m}^{3}\right)\end{array}$ & $\begin{array}{c}\text { Soil temperature } \\
\left({ }^{\circ} \mathrm{C}\right)\end{array}$ \\
\cline { 2 - 6 } & 1 & 0.108 & 20.40 & 0.109 & 19.60 \\
\hline \multirow{3}{*}{$\begin{array}{l}\text { After } \\
\text { inflow }\end{array}$} & 2 & 0.164 & 20.40 & 0.065 & 19.60 \\
\cline { 2 - 6 } & 1 & 0.049 & 20.50 & 0.035 & 19.50 \\
\cline { 2 - 6 } & 2 & 0.038 & 20.60 & 0.079 & 19.50 \\
\cline { 2 - 6 } & 4 & 0.134 & 20.80 & 0.130 & 19.80 \\
\hline
\end{tabular}


Table 2: Flow data for tap water inflow into rain garden.

\begin{tabular}{|l|l|c|c|c|c|}
\hline \multicolumn{2}{|c|}{} & \multicolumn{2}{|c|}{ Trial 1 (1 December 2020) } & \multicolumn{2}{c|}{ Trial 1 (11 December 2020) } \\
\cline { 3 - 6 } \multicolumn{2}{|c|}{} & $\begin{array}{c}\text { Quantity } \\
(\mathrm{mL})\end{array}$ & $\begin{array}{c}\text { Nitrate } \\
\text { concentration } \\
(\mathrm{ppm})\end{array}$ & $\begin{array}{c}\text { Quantity } \\
(\mathrm{mL})\end{array}$ & $\begin{array}{c}\text { Nitrate } \\
\text { concentration } \\
(\mathrm{ppm})\end{array}$ \\
\hline $\begin{array}{l}\text { Wood } \\
\text { mulch- } \\
\text { mixed soil }\end{array}$ & Inflow & 10,500 & $\mathrm{~N} / \mathrm{A}$ & 10,500 & N/A \\
\cline { 2 - 6 } & Runoff & 3,750 & 1,333 & 3,000 & 1,042 \\
\hline Only soil & Inflow & 10,500 & N/A & 10,500 & N/A \\
\cline { 2 - 6 } & Runoff & 1,850 & 833 & 1,180 & 750 \\
\hline
\end{tabular}

mulch mixed in (likely due to the additional mixing of soil, leading to larger voids). Table 2 also illustrates nitrate/nitrite levels decreasing slightly more in the soil from the first to the second date in the wood mulch-mixed box, in comparison to the milder decrease in the control box. This variation may be attributed to a lack of precision associated with nitrate test strips, as the samples were diluted prior to nitrate measurement. The standard deviations of the nitrate measurements ranged from $144 \mathrm{ppm}$ (for both soils on 1 December 2020) to 72 ppm (for both soils on 11 December 2020). Overall, this study provided evidence for the claim that wood chips can reduce the amount of nitrates in soil [7].

\section{RAIN GARDEN DESIGN}

The purpose of this section is to initialize the design for a rain garden at a real-world location in New York City, choosing a site from the GIS green infrastructure map available publicly [8]. This design was incorporated at 30-02 48th Ave, Long Island City, NY 11101, where there is currently a 13 feet $\times 5$ feet right-of-way bioswale. It is a Type A design, which means it is built on stone columns [9]. Columns are typically used during rain garden/bioswale construction for affordability, ease of use, or when the water table is too high. However, they make sacrifices when it comes to load handling and retention.

The alternative design presented by this report is for a hydraulically connected rain garden (HCRG), which consists of two rain gardens connected by an underground layer of open base. This is a strategy used to increase the size (and therefore retention capacity) of rain gardens, while complying with the imposed 20 feet maximum. The separation between the two rain gardens is 5 feet long, allowing for pedestrians to cross. The planting schedule is taken for a mixed sun/shade site at a west facing location [9]. A diagram of the HCRG is seen in Fig. 3.

Each half of the HCRG will have transverse dimensions of 20 feet $\times 5$ feet, leading to a combined surface area of 200 square feet, corresponding to the local impervious tributary area of 7,450 feet. Furthermore, it will be a Type $C$ practice, and use a stormwater chamber, which will allow for bonus retention and better be able to handle any loads. Storage calculations were done, assuming maximum retention, with NYCDEP's stormwater calculation table for on-site GI Practices [10]. With 1.5 feet of porous engineered soil and 1.5 feet of sub gravel, the HCRG is designed to allow 238.3 cubic feet of infiltration, with an additional 287.5 cubic feet of storage, for a total of 525.8 cubic feet of rainfall captured. This will account for $38 \%$ of the corresponding impervious surface for a 1.25 inches rainfall storm.

Additional calculations were done to determine several parameters for the rain garden practice. Flow due to the New York 5-year storm of 5.95 inches/hour was found to be $0.81 \mathrm{cfs}$ of inflow. The effective infiltration depth of water was determined to be 


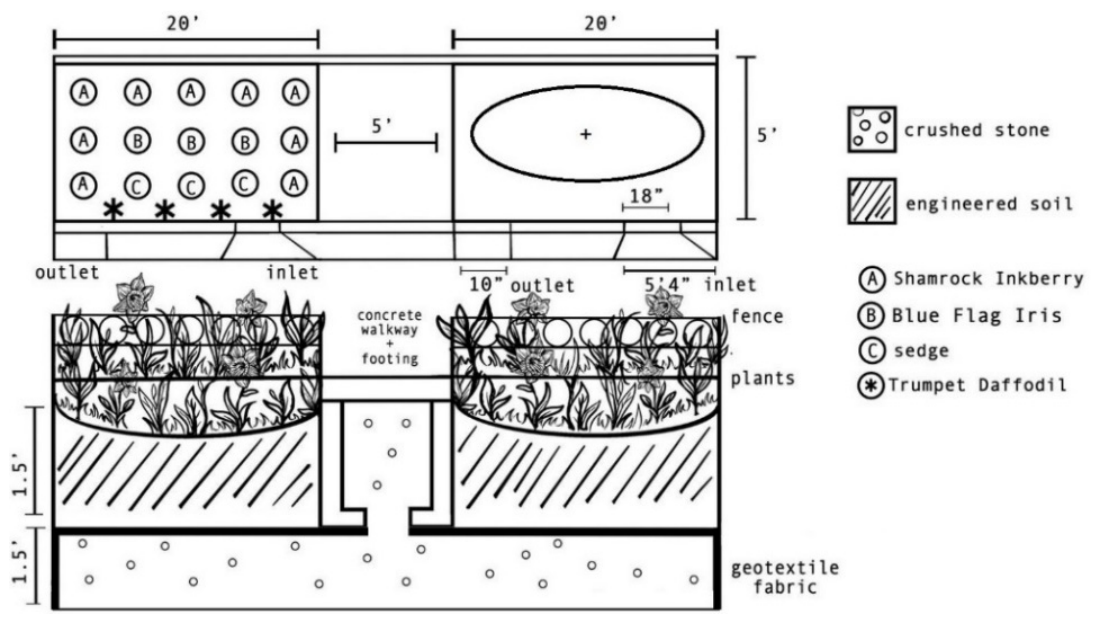

Figure 3: Overhead and cross-sectional views of hydraulically connected rain garden, including planting schedule and grading plan. Low point of grade is 3 inches below edges.

17.25 inches, and designed to drain fully over 57.5 hours. With an inlet with a base of 18 inches and a curb height of 6 inches, the maximum allowable flow was calculated to be $17.24 \mathrm{cfs}$ [11]. Finally, the greened acres were determined. Greened acres signify the area impervious land which, when covered evenly with 1 inch of rainwater, manages an equivalent amount of water to the given GI practice. For this rain garden, the greened acres were found to be 0.145 acres [12].

\section{MODELLED RAIN GARDEN SETUP}

The theory behind the hypothetical rain garden was combined with the experimental procedure of the green roof model to begin a further study. This study examines various parameters regarding stormwater retention and filtration through the construction and analysis of a model rain garden. The study was carried out over the month of March 2021 in the Fluids Laboratory at 41 Cooper Square, New York, NY. The rain garden model was constructed as per NYCDEP Green Infrastructure standards [9]. The model layers during construction can be seen in Fig. 4.

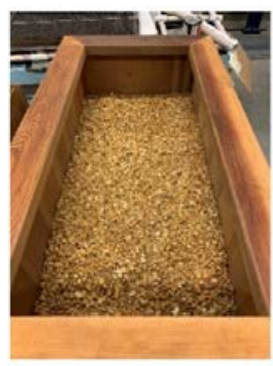

(a)

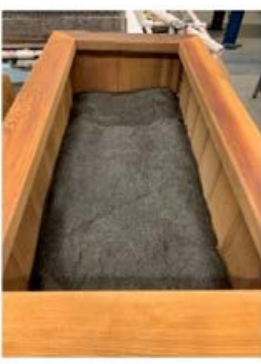

(b)

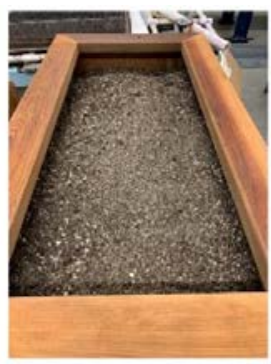

(c)

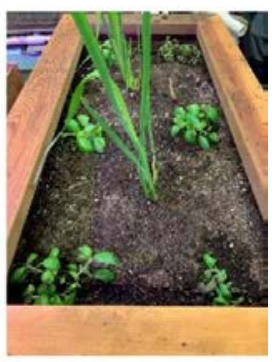

(d)

Figure 4: Layers of model rain garden. (a) 1.5 cubic feet of gravel; (b) Geotextile fabric; (c) 1.5 cubic feet of soil; and (d) Six sweet basil and two blue flag irises. 
During setup, holes were first drilled at the base of one of the shorter ends of the box. The PVC pipe was then affixed over this, to allow for a path for runoff. Beyond this point, the model setup mirrored that of a real rain garden. Rain gardens are typically constructed from the bottom up, with a crushed stone base, a layer of geotextile fabric, a layer of engineered soil equivalent to the volume of the crushed stone, and finally a layer of plants [6]. For the model 1.5 cubic feet of gravel was poured over the base, after which it was covered with a layer of geotextile fabric, which was then coated with 1.5 cubic feet of engineered soil, which was then planted with two blue flag iris plants and six sweet basil plants. This process can be seen in Fig. 4. A clip-on lamp which featured a combination of blue and red light (for maximum photosynthesis) was affixed to the box, and set to run for 12 hours daily to allow for plant growth. This lamp, as well as the runoff pipe, can be seen in Fig. 5.

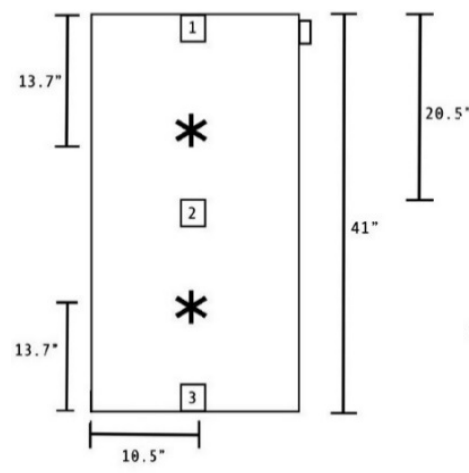

* = Blue Flag Iris<smiles></smiles>

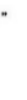

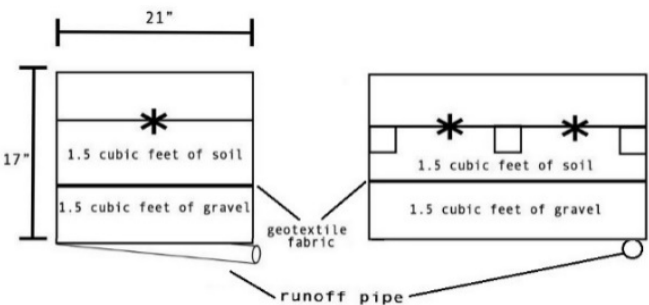

(a)

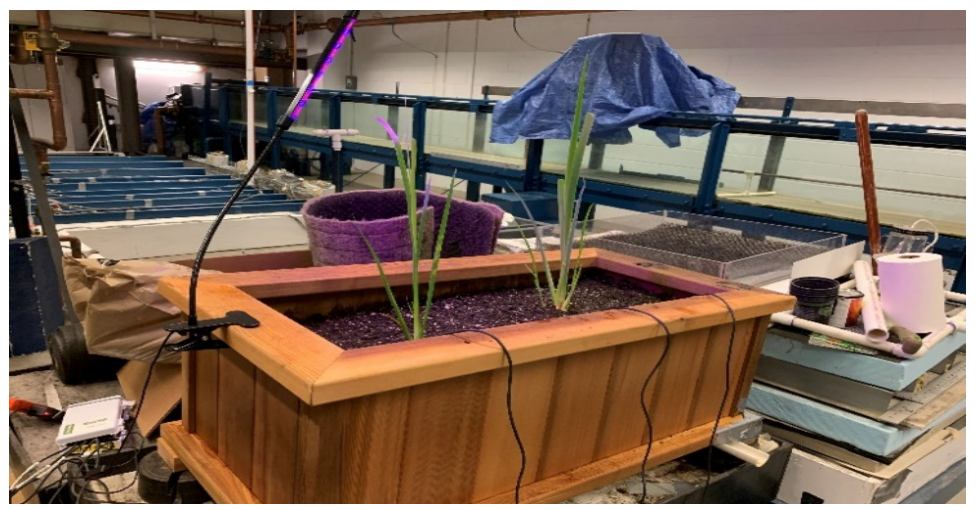

(b)

Figure 5: Views of model rain garden. (a) Dimensioned diagram showing locations of probes and plants; and (b) Photograph of complete rain garden with visible probe cables, lamp, and runoff pipe.

While the setup and procedure were similar to the previously mentioned green roof model study, several improvements were incorporated to improve the significance of the results. One key difference is the usage of plants in this model. Blue flag iris was chosen as the main plant for stormwater absorption, as is the primary choice of perennial for NYCDEP rain 
gardens at sites with mixed sun and shade [9]. Sweet basil plants were added, to complement the blue flag iris, but unfortunately did not survive the duration of the experiment due to an irregular watering schedule. TEROS moisture probes were added as seen in Fig. 5.

Furthermore, additional parameters were measured to increase the validity of the study. In addition to soil moisture/temperature, quantity of inflow/runoff, and runoff nitrates, measurements were recorded for $\mathrm{pH}$ of inflow/runoff, temperature of inflow/runoff, and electrical conductivity. Electrical conductivity (EC) is important for understanding salt concentrations in soil, which can affect plant growth in the rain garden. EC can also be used to estimate soil nitrate levels in non-saline soils with the formula $\mathrm{N}=140 \times \mathrm{EC}$. Nitrogen fertilizer is known to increase salinity, and consequently EC as well [13].

Preliminary runs showed that tap water runoff from the rain garden was not nitrogen free, illustrating that the soil already had a certain amount of nitrogen present (as plants thrive in nitrogen-rich soil). The following strategy was therefore devised to determine the rain garden's capture of nitrogen from contaminated inflow. (1) A baseline nitrate concentration was established from the outflow after running tap water through the rain garden. (2) After this was known, a solution with known nitrogen levels was run through the rain garden, and this outflow also had its nitrogen levels determined. (3) The difference between the soil baseline nitrogen + the known nitrogen levels and the runoff from the nitrogen-contaminated water through the rain garden was the amount of nitrogen which the rain garden capture.

\section{RESULTS}

For all trials, 9,000 $\mathrm{mL}$ of water was poured over the rain garden, corresponding to 1 inch/hour of rainfall, which is the 1 hour 2-year storm in New York City [14]. Trial 1 used tap water, Trial 2 used water with 1,000 ppm of nitrogen for a singular storm event, and Trial 3 used 1,000 ppm nitrogen inflow after an initial 1 inch/hour tap water storm 2 hours previously. Of these inflows, $46 \%, 54 \%$, and $59 \%$ of the flow emerged for Trial 1, 2, and 3, respectively. The remaining inflow was either absorbed by the plants and exited the system via evapotranspiration, or filled voids in the soil. Evapotranspiration is assumed to be roughly negligible for this experiment [15]. It is seen that with a second storm event, the retention capacity of the rain garden may decrease. Eqn (1) illustrates an example water balance equation for the model. Of the measured parameters, soil moisture behaved as expected. From Tables 3, 5 and 8, all trials had three probes with lower moisture at the beginning, much higher immediately after inflow, and a slight drop following runoff drainage. Trials 1 and 3 had warmer inflow than Trial 2 and this showed an effect in the soil temperature changes; the temperatures gradually rose for Trials 1 and 3 (as seen in Tables 3 and 7), while they dropped during Trial 2 (from Table 5). In Trials 1 and 2, the runoff temperature was $18^{\circ} \mathrm{C}$, despite inflow being warmer for Trial 1 and cooler for Trial 2, as seen in Tables 4 and 6, respectively. In all cases, the $\mathrm{pH}$ decreased from inflow to outflow, although adding the nitrogen fertilizer decreased the initial $\mathrm{pH}$ by 0.5 . This shows that the rain garden is slightly acidic, as suits the plant growth. However, the $\mathrm{pH}$ only dropped by 0.5 for Trial 3 , unlike the first two trials where it dropped by 1 , showing that multiple storm events may reduce acidity. Furthermore, despite Trial 3 undergoing a second storm event, the soil water content did not appear to differ drastically from Trial 2. Tables 3, 5, and 8 also display the electrical conductivity, which followed no particular pattern in Trial 1 to hover around the same values at all three data points. For Trials 2 and 3, however, there was a marked increase in EC as expected, as EC corresponds with salinity, which nitrates increase. Regarding nitrogen runoff, $500 \mathrm{ppm}, 800 \mathrm{ppm}$, and 1,000 ppm emerged for Trials 1, 2, and 3, respectively. This shows that the soil for this rain garden had a baseline of $500 \mathrm{ppm}$, and was able to capture $70 \%$ of the nitrogen from singular storm event and only $50 \%$ from the second storm. This 
nitrogen was captured by the soil, and is either consumed by the plants, or transformed into nitrous gas via denitrification (as occurs in standard bioretention systems) [16]. A sample nitrogen balance equation was done in eqn (2), accounting for the nitrogen already present in the rain garden prior to contamination. This highlights the fact that the base nitrogen from the rain garden which contaminated the runoff cannot be ignored; $1,000 \mathrm{ppm}$ flow entered the rain garden, and $800 \mathrm{ppm}$ emerged after one storm, while 1,000 ppm emerged after two storms. This would bring the nitrogen reduction percentage to $20 \%$ for one storm and $0 \%$ for two storms. This model does not approach $100 \%$ nitrogen capture as cited by NYCDEP.

Example equation for water balance of model rain garden. Values from Trial 2 are used.

$$
\begin{gathered}
P=R+E T+\Delta S \\
9,000 m L=4,850 m L+0 m L+4,150 m L
\end{gathered}
$$

Equation for nitrogen balance of model rain garden. Values from Trial 2 are used.

$$
\begin{gathered}
N_{\text {inflow }}+N_{\text {soil baseline }}=N_{\text {runoff }}+N_{\text {soil storage }} \\
9 g N+21.25 g N=3.88 g N+26.37 g N
\end{gathered}
$$

\begin{tabular}{|c|c|c|c|c|}
\hline \multicolumn{5}{|c|}{ Trial 1 (30 March 2021) } \\
\hline & $\begin{array}{l}\text { Probe } \\
\text { number }\end{array}$ & $\begin{array}{c}\text { Water } \\
\text { content } \\
\left(\mathrm{m}^{3} / \mathrm{m}^{3}\right)\end{array}$ & $\begin{array}{l}\text { Soil temperature } \\
\qquad\left({ }^{\circ} \mathrm{C}\right)\end{array}$ & $\begin{array}{c}\text { Bulk electrical } \\
\text { conductivity } \\
(\mathrm{mS} / \mathrm{cm})\end{array}$ \\
\hline \multirow{3}{*}{$\begin{array}{l}\text { Before } \\
\text { inflow }\end{array}$} & 1 & 0.171 & 17.70 & 0.438 \\
\hline & 2 & 0.244 & 16.30 & 0.311 \\
\hline & 3 & 0.152 & 17.10 & 0.585 \\
\hline \multirow{3}{*}{$\begin{array}{l}\text { Immediately } \\
\text { after inflow }\end{array}$} & 1 & 0.302 & 20.60 & 0.438 \\
\hline & 2 & 0.367 & 18.50 & 0.216 \\
\hline & 3 & 0.293 & 18.10 & 0.989 \\
\hline \multirow{3}{*}{$\begin{array}{l}\text { After runoff } \\
\text { drainage }\end{array}$} & 1 & 0.271 & 20.90 & 0.407 \\
\hline & 2 & 0.338 & 19.80 & 0.233 \\
\hline & 3 & 0.256 & 18.90 & 0.958 \\
\hline
\end{tabular}

Table 3: TEROS soil probe data for tap water inflow into rain garden.

Table 4: Flow data for tap water inflow into rain garden.

\begin{tabular}{|l|c|c|c|c|}
\hline \multicolumn{5}{|c|}{ Trial 1 (30 March 2021) } \\
\hline & Quantity $(\mathrm{mL})$ & $\mathrm{pH}$ & Temperature $\left({ }^{\circ} \mathrm{C}\right)$ & $\begin{array}{c}\text { Nitrate concentration } \\
(\mathrm{ppm})\end{array}$ \\
\hline Inflow & 9.000 & 6.5 & 22 & 5 \\
\hline Runoff & 4,150 & 7.5 & 18 & 500 \\
\hline
\end{tabular}


Table 5: TEROS soil probe data for nitrogen-contaminated water inflow into rain garden.

\begin{tabular}{|l|c|c|c|c|}
\hline \multicolumn{5}{|c|}{ Trial 2 (7 April 2021) } \\
\hline \multirow{2}{*}{$\begin{array}{l}\text { Before } \\
\text { inflow }\end{array}$} & $\begin{array}{c}\text { Probe } \\
\text { number }\end{array}$ & $\begin{array}{c}\text { Water } \\
\text { content } \\
\left(\mathrm{m}^{3} / \mathrm{m}^{3}\right)\end{array}$ & $\begin{array}{c}\text { Soil temperature } \\
\left({ }^{\circ} \mathrm{C}\right)\end{array}$ & $\begin{array}{c}\text { Bulk electrical } \\
\text { conductivity }(\mathrm{mS} / \mathrm{cm})\end{array}$ \\
\cline { 2 - 5 } & 2 & 0.277 & 18.50 & 0.108 \\
\hline \multirow{2}{*}{$\begin{array}{l}\text { Immediately } \\
\text { after inflow }\end{array}$} & 3 & 0.336 & 17.90 & 0.113 \\
\cline { 2 - 5 } & 2 & 0.260 & 18.40 & 0.160 \\
\hline \multirow{2}{*}{$\begin{array}{l}\text { After runoff } \\
\text { drainage }\end{array}$} & 3 & 0.318 & 18.1 & 0.164 \\
\cline { 2 - 5 } & 2 & 0.378 & 17.8 & 0.205 \\
\hline
\end{tabular}

Table 6: Flow data for nitrogen-contaminated water inflow into rain garden.

\begin{tabular}{|l|c|c|c|c|}
\hline \multicolumn{5}{|c|}{ Trial 2 (7 April 2021) } \\
\hline & Quantity $(\mathrm{mL})$ & $\mathrm{pH}$ & Temperature $\left({ }^{\circ} \mathrm{C}\right)$ & Nitrate concentration $(\mathrm{ppm})$ \\
\hline Inflow & 9,000 & 6 & 17 & 1,000 \\
\hline Runoff & 4,850 & 7 & 18 & 800 \\
\hline
\end{tabular}

Table 7: TEROS soil probe data for nitrogen-contaminated water inflow into rain garden, following an initial storm event.

\begin{tabular}{|l|c|c|c|c|}
\hline \multicolumn{5}{|c|}{ Trial 3 (26 April 2021) } \\
\hline & $\begin{array}{c}\text { Probe } \\
\text { number }\end{array}$ & $\begin{array}{c}\text { Water content } \\
\left(\mathrm{m}^{3} / \mathrm{m}^{3}\right)\end{array}$ & $\begin{array}{c}\text { Soil temperature } \\
\left({ }^{\circ} \mathrm{C}\right)\end{array}$ & $\begin{array}{c}\text { Bulk electrical } \\
\text { conductivity (mS/cm) }\end{array}$ \\
\hline \multirow{2}{*}{$\begin{array}{l}\text { Before } \\
\text { inflow }\end{array}$} & 1 & 0.280 & 19.80 & 0.129 \\
\cline { 2 - 5 } & 2 & 0.322 & 19.40 & 0.238 \\
\hline \multirow{2}{*}{$\begin{array}{l}\text { Immediately } \\
\text { after inflow }\end{array}$} & 3 & 0.259 & 19.40 & 0.167 \\
\cline { 2 - 5 } & 2 & 0.317 & 20.00 & 0.186 \\
\hline \multirow{2}{*}{$\begin{array}{l}\text { After runoff } \\
\text { drainage }\end{array}$} & 3 & 0.359 & 19.60 & 0.274 \\
\cline { 2 - 5 } & 2 & 0.306 & 19.50 & 0.214 \\
\cline { 2 - 5 } & 3 & 0.294 & 21.00 & 0.141 \\
\hline
\end{tabular}

Table 8: Flow data for nitrogen-contaminated water inflow into rain garden, following an initial storm event.

\begin{tabular}{|l|c|c|c|c|}
\hline \multicolumn{5}{|c|}{ Trial 3 (26 April 2021) } \\
\hline & Quantity $(\mathrm{mL})$ & $\mathrm{pH}$ & Temperature $\left({ }^{\circ} \mathrm{C}\right)$ & $\begin{array}{c}\text { Nitrate concentration } \\
(\mathrm{ppm})\end{array}$ \\
\hline Inflow & 9,000 & 6 & 22 & 1,000 \\
\hline Runoff & 5,250 & 6.5 & 20 & 1,000 \\
\hline
\end{tabular}




\section{CONCLUSION}

The initial purpose of this report was to design a theoretical rain garden, as an improved alternative for an existing green infrastructure practice in Long Island City, New York. This alternative design was for a Type $\mathrm{C}$ hydraulically connected rain garden, and was found to be able to capture $38 \%$ of all of the rainwater which the corresponding impervious area would receive during a 5-year storm. Its corresponding green acreage was calculated to be 0.145 acres of impervious surface.

Following this design, an experiment was designed to research the effectiveness of rain gardens through the construction and study of a model rain garden practice. Drawing from a previous study which examined nitrate treatment in a green roof model, this rain garden study was structured to determine and analyse a rain garden's capability for water retention and filtration. However, there was a certain amount of nitrogen already present in the soil used, most likely added to promote plant growth. During the trials, it was seen that nitrogen leached from the soil into the runoff. While the rain garden was able to reduce nitrogen from contaminated inflow to an extent, it was unable to come close to the $100 \%$ reduction cited by the NYCDEP. Further testing of this claim is recommended, to determine the true filtration efficiency of rain garden practices.

\section{REFERENCES}

[1] NYC Department of Environmental Protection (NYCDEP), NYC Green Infrastructure Plan, 2010.

https://www1.nyc.gov/assets/dep/downloads/pdf/water/stormwater/greeninfrastructure/nyc-green-infrastructure-plan-2010.pdf. Accessed on: 1 Sep. 2020.

[2] United States Environmental Protection Agency, Benefits of green infrastructure. https://www.epa.gov/green-infrastructure/benefits-green-infrastructure. Accessed on: 1 Oct. 2020.

[3] Denchak, M., Green infrastructure: How to manage water in a sustainable way. National Defense Research Council, 2019. https://www.nrdc.org/stories/greeninfrastructure-how-manage-water-sustainable-way. Accessed on: 1 Feb. 2020.

[4] NYC Stormwater Management Program, NYCDEP, 2020. https://www1.nyc.gov/ assets/dep/downloads/pdf/water/stormwater/ms4/nyc-swmp-plan-full.pdf. Accessed on: 1 Sep. 2020.

[5] NYCDEP, New York City Stormwater Design Manual. 2016. https://www1.nyc.gov/ assets/dep/downloads/pdf/water/stormwater/ms4/stormwater-manual-final.pdf. Accessed on: 1 Oct. 2020.

[6] NYCDEP, NYC Green Infrastructure: 2014 Annual Report. 2014. https://www1.nyc.gov/assets/dep/downloads/pdf/water/stormwater/greeninfrastructure/gi-annual-report-2014.pdf. Accessed on: 1 Jun. 2020.

[7] Sanyal, H., Crop Nitrates Research. Unpublished manuscript, The Cooper Union for the Advancement of Science \& Art, 2020.

[8] NYCDEP, DEP Green Infrastructure Program Map. https://www.arcgis.com/home/ webmap/viewer.html?webmap=a3763a30d4ae459199dd01d4521d9939\&extent=74.3899,40.497,-73.3757,40.9523. Accessed on: 1 Aug. 2020.

[9] NYCDEP, Standard designs and guidelines for green infrastructure practices, 2020. https://www1.nyc.gov/assets/dep/downloads/pdf/water/stormwater/green-

infrastructure/green-infrastructure-standard-designs.pdf. Accessed on: 1 Aug. 2020. 
[10] NYCDEP, Stormwater calculation table for on-site GI practices. https://www1.nyc.gov/assets/dep/downloads/pdf/water/stormwater/greeninfrastructure/nyc-green-infrastructure-onsite-design-manual-appendix-dstormwater-calculation-table.xlsx. Accessed on: 1 Aug. 2020.

[11] NYCDEP, NYC Green Infrastructure On-site Design Manual, 2019. https://www1.nyc.gov/assets/dep/downloads/pdf/water/stormwater/greeninfrastructure/nyc-green-infrastructure-onsite-design-manual-v1.pdf. Accessed on: 1 Aug. 2020.

[12] NYCDEP, NYC Green Infrastructure 2018 Annual Report, 2018. https://www1.nyc.gov/assets/dep/downloads/pdf/water/stormwater/greeninfrastructure/gi-annual-report-2018.pdf. Accessed on: 1 Jul. 2020.

[13] United States Department of Agriculture, Soil electrical conductivity. https://www.nrcs.usda.gov/Internet/FSE_DOCUMENTS/nrcs142p2_053280.pdf. Accessed on: 1 Mar. 2021.

[14] Cornell University, Intensity duration frequency curves for New York state. http://ny-idf-projections.nrcc.cornell.edu/. Accessed on: 21 Apr. 2021.

[15] Alvizuri, J., Cataldo, J., Smalls-Mantey, L. \& Montaldo, F., Intensity duration frequency curves for New York state. Cornell University, Green Roof Thermal Buffering and Buildings, Period 151, 2017.

[16] Stander, E.K. \& Borst M., Bioretention monitoring: Designing rain gardens to promote nitrate removal. 2008 International Low Impact Development Conference, 2008. 